II. - Carcass AND MEAT QUALITY

\title{
Comparison between three methods for measurement of the back fat thickness in the pig
}

\author{
D. BRAULT, D. BOUTIER, A. DERRIEN, M. MOLENAT \\ Station de génétique quantitative et appliquée, \\ Centre national de Recherches zootechniques, I.N.R.A., \\ $7835^{\circ}$ Jouy-en-Josas (France)
}

Three methods used for measuring back fat thickness were compared: ultra-sound measurement on the live animal, endoscopic measurement and measurement on the split of the carcasses. The results showed a good correlation between the figures obtained with the different techniques: the correlation coefficients were between 0.64 and $0.8 \mathrm{r}$. However, the values obtained depended on the method used. The ultra-sound measurement seems to underestimate the back fat thickness and a new standardization of the apparatus has to be considered.

\section{Meat production by entire or castrated male pigs of the Pietrain or Belgian Landrace types}

\author{
B. DESMOULIN, M. BONNEAU \\ Station de Recherches sur l'Élevage des Porcs \\ Centre national de Recherches zootechniques, I.N.R.A., \\ $7835^{\circ}$ Jouy-en-Josas (France)
}

Seventy two entire or castrated male pigs (Pietrain or Belgian Landrace) were produced and compared in order to show the decrease of the lean meat yield in castrated males and that of the meat quality in entire males. The main results were the following:

- The castrated males fed ad libitum consumed $25-40 \mathrm{~kg}$ food more than the entire males for a similar growth. Hyperphagia was more marked in the Pietrain castrates ( 18 p. Ioo) and the feed efficiency was lower $(-\mathrm{I} 7 \mathrm{p}$. Ioo) in the castrates of the Belgian Landrace. At a weight of $90 \mathrm{~kg}$ the muscle content of the carcass was reduced by $7 \mathrm{p}$. 10o. At the heavy stage (I ooI I $\mathrm{kg}$ ), the increase of fatness in the Pietrain castrated males ( + I 5 p. Ioo) was much higher than in the Belgian Landrace $(+6,8 \mathrm{p}$. I0o). In consequence, the differences due to selection between the male lines are counterbalanced after castration.

The meat quality of the entire or castrated males was estimated at two levels. The very pronounced muscle defects in the Pietrain breed were characterized by the lower pH-values $(\leqslant 5.5)$ reached within $45 \mathrm{mn}$ post mortem. These within breed defects also affected the castrated males. The boar taint defects due to storage of androstenone in the fat of the entire males were very frequent in the Pietrain animals from the weight of $90 \mathrm{~kg}(28$ to $59 \mathrm{p}$. Ioo of the judgments according to tests). In the Belgian Landrace only a minority (4 to Io p. Ioo of the judgments) was involved at the light stage $(90 \mathrm{~kg})$. However the frequency of defects increased very significantly at the heavy stage (ro to $35 \mathrm{p}$. Ioo of the judgments). 